\title{
The Effect of Coumarin Derivatives(compounds) on the Vibrio cholerae Isolates from Different Clinical Iraqi Sources Fatima.R.Abdul", Nehad.A.Taher ${ }^{*}$, ,Ashraf S.Hassan" and Enaam H. Batah ${ }^{*}$
}

*Department of Biology, College of Science, Al-Mustansiryha University ,Baghdad ,Iraq. Abstract

From a large number of bacterial samples collected from different hospital in Iraq in central health laboratory ,only ten isolates were identified primary as Vibrio. A number of morphology and biochemical test were carried out to complete this identification that showed all bacterial isolates were related to Vibrio cholerae. In this study all Vibrio isolates were investigated for Bio typing and the result showed that all (10) isolate were related to (Eltor biotypes).Also, the susceptibility test towards eight antibiotics were carried out .

Results shows that ciprofloxacin , Norfloxacin, Erythromycin, Ampicillin, ceftriaxone and Amikacin were the most effective antibiotics and their resistance percentage were 20\%,20\%,20, 20,30\% and 30\% respectively, While Chloramphenicol and Co- trimoxazole were less effective and their resistance percentage were $90 \%$ both of them. Three $(3,5,6)$ isolates $V$. cholerae were selected depending on results of antibiotics sensitivity tests as showed multiple -antibiotics resistance(100\%).

Then tested to study the effect of coumarin derivatives compounds $(1,2,3)$ which showed inhibitory effect on $V$. cholera $(3,5,6)$ isolates and the compound ( 3 ) showed the highest antibacterial activity of $(12,15,14 \mathrm{~mm})$ of inhibition zone diameter against $V$. cholera $(3,5,6)$ isolates respectively.

Also, these Iraqi isolates $(3,5,6)$ used to test the effect of acridine orange $(0.1 \%)$ as acuring agent, the results showed that all (3) isolates $V$. cholerae were sensitive to (ciprofloxacin, ceftrixone and Norfloxacin), While the rest were resistance to remained five antibiotics.

The results of Agarose -gel electrophoresis of both normal V. cholerae $(3,5,6)$ and cured isolates showed the presence of chromosomal and plasmid DNA bands in the normal case, While only chromosomal DNA bands occur with $V$. cholerae (isolate 8) treated with an acridine orange at concentration of $\left(10^{-2}\right.$ to $\left.10^{-4}\right)$.

Keywords: Vibrio cholera, Coumarin derivatives, Acridine orange.

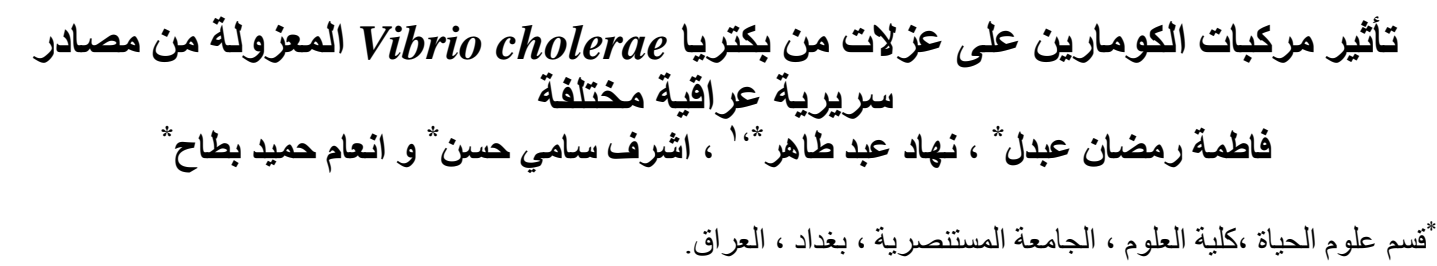

الخلاصة

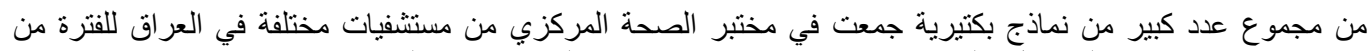

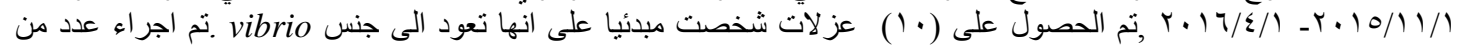

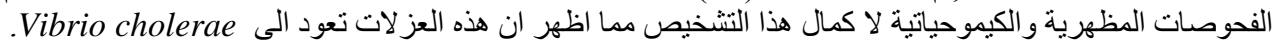

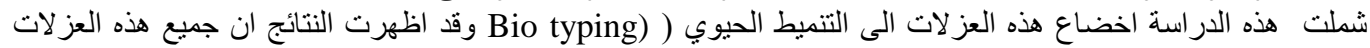

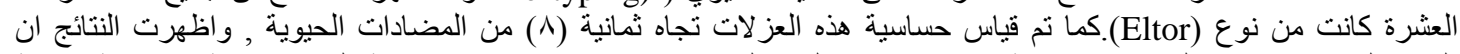

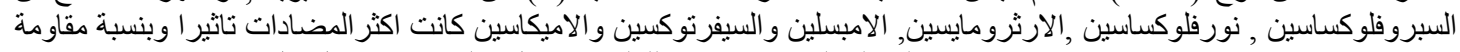

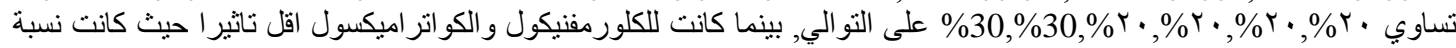

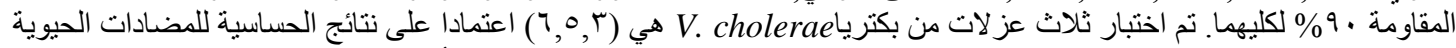

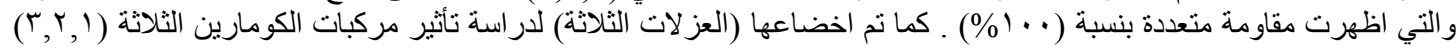

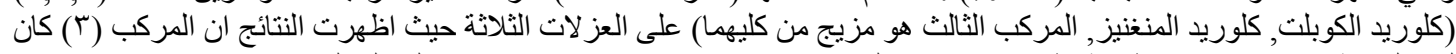

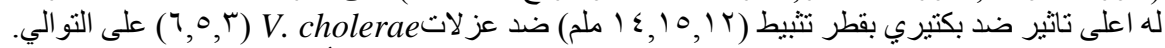

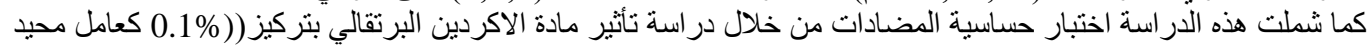

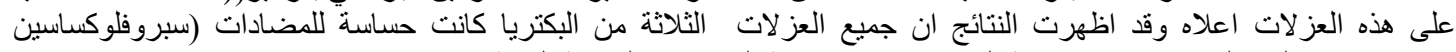

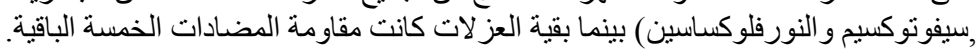

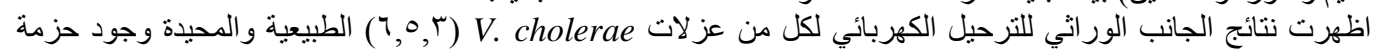

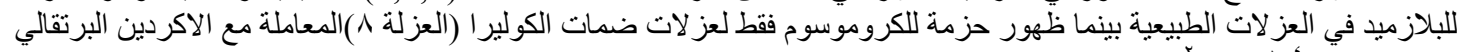

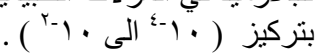
الكلمات المفتاحية : بكتريا لو (Vibrio cholera، مركبات الكومارين ، الاكردين البرتقالي .

${ }^{1}$ Corresponding author E-mail: dnahad17@yahoo.com

Received: 1 /12/2016

Accepted: $20 / 6 / 2017$ 


\section{Introduction}

Cholera as a disease is an acute diarrheal illness caused by $V$. cholerae infection of intestine, by how may infect 3-5 million person and may cause the death to 100,000 to 120,000 for each year, if don't have the therapy ${ }^{(1)}$. V.choleraee is a Gram negative, curved rod bacterium, colonize the small intestine, naturally habitat abrakish or salt water $^{(2)}$. When ingested, V. cholerae can cause diarrhea and vomiting in the host within several hours to 2-3 days of ingestion ${ }^{(3,4)}$.

The modern genetic studies that are achieved on the cholerae bacteria (Eltor biotype) showed that it contains two circular chromosomes instead of one ${ }^{(5)}$. One of the two chromosomes has large size, it consists of 3 million base pair, it contains the most necessary genes to produce cytotoxin $\mathrm{CT}$ as well as the proteins which enter in metabolic pathways for the cell ${ }^{(6)}$, as well as it includes the important genes to DNA replication, the cell division, genes transcription,protein translation and building the cell well as well as the genes that encoded about the virulence factors such as toxin corregulated pili (tcpA) and $(\text { tox } R)^{(7)}$.

Heinemann et al referred to the existence type of plasmids is called $\mathrm{R}-$ plasmid which is existed in genetic content of the cholerae bacteria, this factor is responsible for bacteria resistance for many antibiotics ${ }^{(8)}$.The transferring of R-plasmid is easy where it is transferred to bacteria (E. coli $-\mathrm{K} 12)$ to study the effect on the bacteria which is transferred to it in terms of resistance and sensitivity to the antibiotics ${ }^{(9)}$.

$V$. choleraee bacterial was sensitive to a large number of antibiotics until the seventh decade of the twentieth century, However, the widespread and non programmable using of antibiotics leads to the emergence of resistant strains to many antibiotics ${ }^{(10)}$. Until $1970, V$. choleraee was sensitive to each of antibiotics(Tetracyclin,Ampicillin,Chloramphe nicol), and in the eighties, It emerged resistant isolates to many antibiotics such as Ampicillin, Trimethoprime andTetracycline ${ }^{(11)}$.

The coumarin compound afragrant organic chemical class (warfarin) benzopyrone, which is colorless crystalline substance in standard state, it it's a natural substance found in many plants on their biosynthesis in plants occur via hydroxylation, glycolysis and cyclization of cinnamic acid. ${ }^{(12,13)}$

The coumarin compounds have important biological applications, it has been used as antifungal agents and as anticoagulants, and also to organize the growth of plants ${ }^{(14,15)}$.

Acridine orange (Ao) is an organic compound used in nucleic acid selective fluorescent cationic dye useful for cell cycle determination at502nm and an emission maximum shifts to460nm (blue). AOwill also enter acidic compartments such aslysosomes and become pronoated and sequestered in theselow $\mathrm{pH}$ conditions ,the dye will emit orange light .Thus Acridine Orange can be used to identify engulfed apoptotic cells, because it will fluoresce upon engulfment .The dye is oftenused in epi florescence microscopy and flow cytometry analysis of cellular physiology and cell cycle status ${ }^{(15)}$

\section{Materials and Method}

\section{Samples collection}

Ten bacterial samples used in this study were obtained from central healthy laboratory collected from different hospital in Iraq.

\section{Bacterial diagnosis}

Initial diagnostic depending on Gram reaction and morphological characteristic of the colonies based on bacterial growth on thiosulphate citrate bile salt sucrose agar (TCBS) and Blood agar, as well as the number of biochemical test ${ }^{(16)}$, and VITEK 2 Compact system. The second technique Biotyping of bacterial ,the biotype of $V$. cholerae serogroup O1(EItor) was distinguished by the following methods; polymyxinB susceptibility ,heamolysin test and voges-proskaur test ${ }^{(17)}$.

Antibiotic susceptibility test

Disk agar diffusion according to Kirby Baur standardized antimicrobial susceptibility single disk method was carried out toward eight antibiotics (Ciprofloxacin, Norfloxacin, Erythromycin, Ampicillin, ceftriaxone , Amikacin, Chloramphenicol andCotrimoxazole ), Bioanaylyse(Turkey).

The antibiotic resistance percentage detected to each antibiotic as = number of resistance isolate to a specific antibiotic /Total number of tested isolates $\times 100 \%{ }^{(18)}$.

Experimental reparation of ethyl - 6-chloro - $1 \mathrm{H}$-isochromene - 3- carboxylate (S)

In this study three already synthesized coumarin derivatives were used compound (1) $\left(\mathrm{Co}\left(\mathrm{C}_{10} \mathrm{H}_{5} \mathrm{CIO}_{4}\right)_{2} \mathrm{Cl}_{2}\right)$, compound $\left(\mathrm{Mn}\left(\mathrm{C}_{10} \mathrm{H}_{5} \mathrm{CIO}_{4}\right)_{2} \mathrm{Cl}_{2}\right)$ and compound (3) mix of (1) and (2) compounds, and their melting point were detected $\left(71^{\circ} \mathrm{C}=344 \mathrm{~F}\right)$ and prepared as follow:

5-chloro-2-hydroxyl benzaldehyde( 0.56 gm , 0.0036 mole ) and diethyl malonate ( $0.64 \mathrm{gm}, 0.004$ mole $10 \mathrm{~mol} \%$ excess ) were heated with stirring in ethanol ( $95 \%, 20 \mathrm{ml}$ ) until dissolution occurred. Addition of piperidine ( orang . the solution was refluxed 
for 6 hour and on cooling a white crystalline solid formed, crystals of ethyl - 6-chloro - 1 $\mathrm{H}$ - isochromene - 3-carboxylate were isolated by filtration and washed form ethanol, filtered $\left(0^{\circ} \mathrm{C}\right)$, the solid was recrystallized from ethanol, filtered and washed with cold ethanol again.

An ethanolic Solution $(10 \mathrm{ml})$ of the metal salt (metal (II) salts are hydrated chloride ; $\mathrm{MCl} 2$.XH2O ; where : M=, Mn ( II ), co ( II ) ( : X=6, 6,4 and 2, respectively ), was add to methanolic solution of the ligand (2mmole) in methanol $(15 \mathrm{ml})$.

The reaction mixture was then refluxed around $2 \mathrm{hr}$. at $\mathrm{PH}=(6-7)$, a colored precipitate was formed the product was then filtered and re-crystallized with methanol and dried at room temperature ${ }^{(19)}$.

\section{Antimicrobial activity of the coumarin derivatives compounds}

The agar-well diffusion method was used to evaluate the antimicrobial activity of the ( 6 - Chloro - 2 - oxo - 2 Hchromene -3 - carboxylic acid and complexes ) compounds . A bacterial suspension of $\left(1.5 \times 10^{6}\right.$ cells $\left./ \mathrm{ml}\right)$ which obtained by transfer aloopful of bacterial suspension from serial dilutions (stosk, $10^{-1}, \ldots . .10^{-6}$ ) , then streaking on (NA) nutrient agar plates and give acolony number (150 colony / 100ml medium)/dilution ) was inoculated on MullerHinton agar plates. Wells (5 $\mathrm{mm}$ in diameter) were made in solidified agar using a sterile end of Pasteur pipette. An amount of $0.1 \mathrm{ml}\left(2 * 10^{-}\right.$ ${ }^{3} \mathrm{M}$ ) of each compounds was then added to the wells, in addition, one well was filled with DMSO solution(aspecific soluble solution), as a control (19). The plates were put in refrigerator at $4^{\circ} \mathrm{C}$ for $30 \mathrm{~min}$ to allow for diffusion of concentrations via the medium ,then incubated for $24 \mathrm{hrs}$ at $37^{\circ} \mathrm{C}$ and the antimicrobial activity of each compounds was recorded by measuring the inhibition zone around the wells.

Effect of curing agent (acridine orange).

In this part of study the highly $V$. choleraee resistant isolate were used for studying the effect of the curing agent acriding orange concentrations of $\left(0,10^{-1}, 10^{-2}, 10^{-3}, 10^{-}\right.$ ${ }^{4}, 10^{-5}, 10^{-10}$ )by dissolving $0.1 \mathrm{mg}$ of acridine orange in $10 \mathrm{ml}$ D.W.then the above concentrations were prepared and added to a plate of nutrient agar seeded with alawn of nutrient broth (18-24h.) culture of isolates (3and 5). Then ,the antibiotic susceptibility were measured at each concentration ${ }^{(20)}$.

\section{DNA profile by gel electrophoresis}

Bacterial plasmid DNA was extracted from cultured cells using the alkaline SDS method with promega DNA kit described by (21) as follow:

Centrifuge $25 \mathrm{ml}$ of culture, resuspended pellet in $0.5 \mathrm{ml}$ of lysozyme solution containing $(0.3 \mathrm{M} \mathrm{NaOH}, 2 \% \mathrm{SDS})$, mix and incubated at $70^{\circ} \mathrm{C}$ for $15 \mathrm{~min}$, add $0.08 \mathrm{ml}$ of acid phenol/chloroform (1:1)and mix gently, separate phases by centrifugation at $10000 x \mathrm{x}$ for $10 \mathrm{~min}$ and transfer the upper aquous phase to a new Eppendorff tube containing $0.07 \mathrm{M}$ sodium acetate and $0.7 \mathrm{ml}$ isopropanol, centrifuge again for $2 \mathrm{~min}$, the pellet dissolved in $0.05 \mathrm{ml}$ TE buffer, stored at $4^{\circ} \mathrm{C}$ and samples were electrophorated using $0.7 \%$ agarose with $5 \mathrm{v} / \mathrm{cm}$ for $2 \mathrm{~h}$, after ending of electrophoresis process, the gel was exposed to U.V. light with $340 \mathrm{~nm}$ to observe plasmid bands.

\section{Results and Discussion}

All bacterial samples expected to be a $V$. choleraee grown on alkaline peptone water (APW) at $\mathrm{pH} 9.2$ as enrichment media, then transferred to thiosulfate citrate bile salt sucrose agar medium (TCBS) and occurred as yellow brilliant colonies on this medium figure (1).Also , it occurs as comma to S-shaped with red color under the microscope.Then ,a number of biochemical test were carried out and the results showed in Table(1).

Table (1): Biochemical tests of $V$. choleraee isolates .

\begin{tabular}{||l|l||}
\hline \hline Biochemical Test & Results \\
\hline Oxidase & + \\
\hline Catalase & + \\
\hline Kliger Iron Assay & A/K \\
& No gas, No H2S \\
\hline Mannose Resistance & + \\
\hline Voges Proskaur & + \\
\hline Motility & + \\
\hline Urease & + \\
\hline Cholerae red & + \\
\hline \hline
\end{tabular}

All the above results in addition to identification by Vitek system, revealed that all ten Vibrio isolates were related the cholerae species $(100 \%)(15)$.

In this study, all (10) $V$. cholerae isolates were investigated biotyping and the results showed that all $V$. choleraee were O1(Eltor) serotype group(16).Our results was in agreement with the results obtained by ${ }^{(22)}$. 


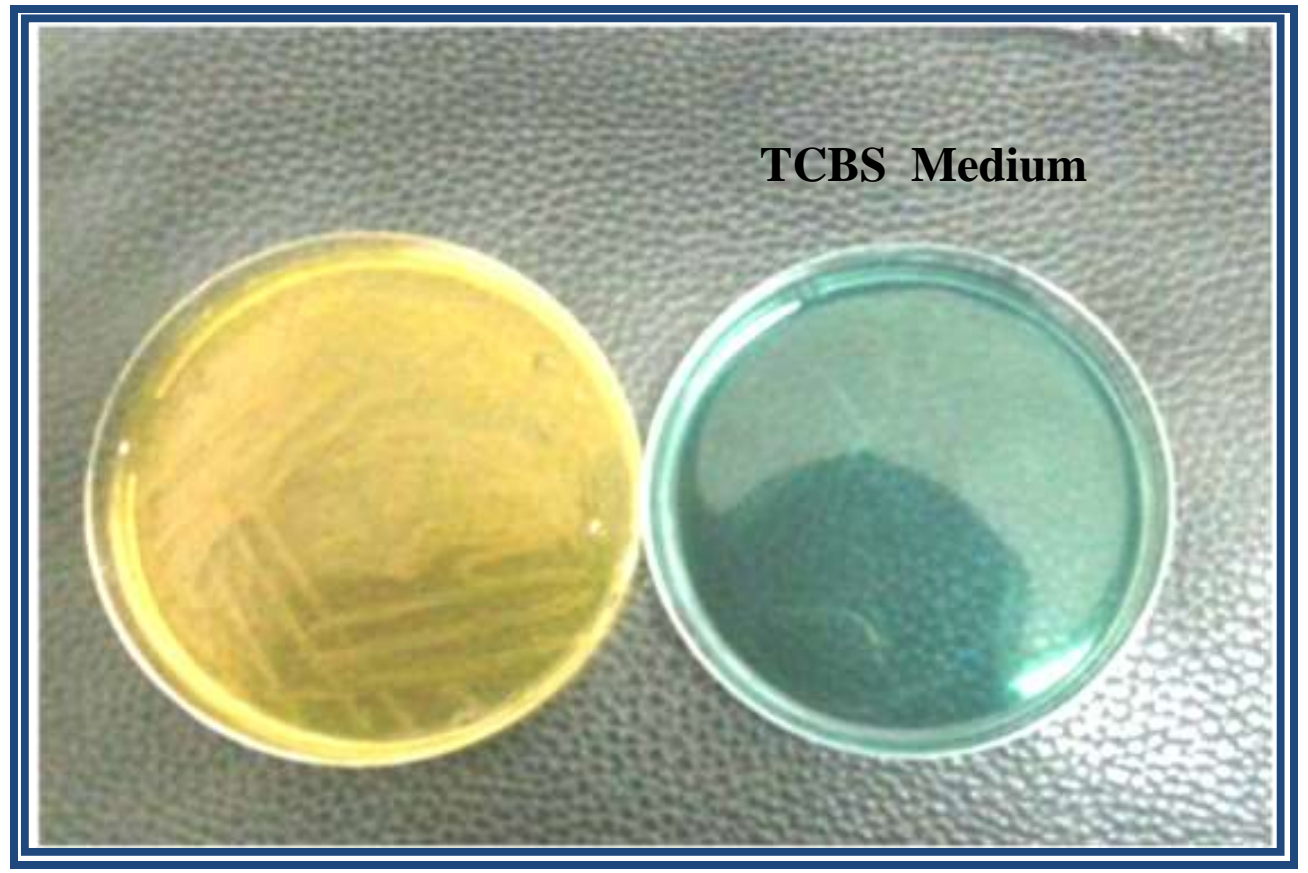

Figure (1): Thiosulfate Citrate bile salt sucrose agar (TCBS) medium for cultivation of $V$. cholerae produce a distinctive yellow colonies.

\section{Antibiotics Susceptibility}

The Susceptibility tests toward eight antibiotics were carried out and results are illustrated in figure (2) showed that ciprofloxacin , Norfloxacin,Erythromycin, Ampicillin, ceftriaxone and Amikacin were the most effective antibiotics and their resistance percentage were $20 \%, 20 \%, 20,30 \%$ and $30 \%$ respectively, While Chloramphenicol and Co- trimoxazole were less effective and their resistance percentage were $90 \%$ both of them. Three isolates $V$. cholerae $(3,5,6)$ were selected depending on results of antibiotics sensitivity tests as showed multiple-antibiotics resistance(100\%).

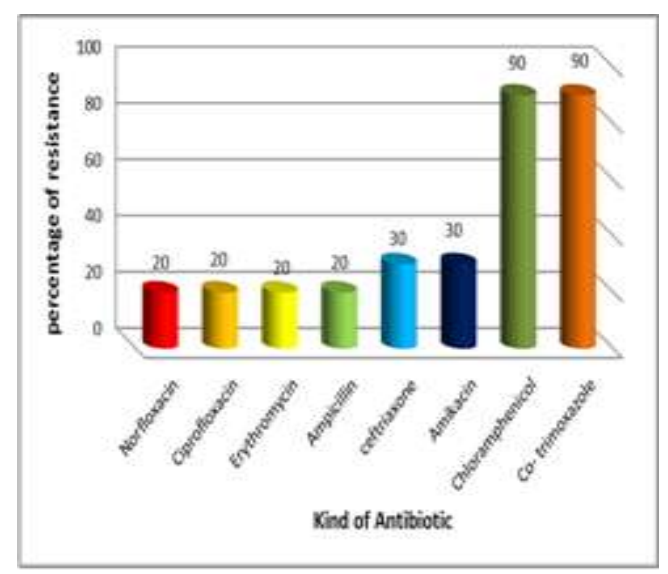

Figure (2): The resistance percentage of $V$. choleraee isolates to antibiotics.
Results agreed with ${ }^{(22)}$ who found that the $V$. choleraee isolates showed a high sensitivity to each of Ampicillin, Ciprofloxacin, Erythromycine, Tetracycline, Gentamicin and Cephalothin, and showed a low resistance $(10 \%)$ and $(20 \%)$ to Cefotaxime and Amikacin respectively, but disagreed with her results when she found that $(80 \%)$ of the environmental isolates were resistance to Amikacin.

The antimicrobial activityof coumarin derivatives(compounds) compounds against V. choleraee.

The antimicrobial activity of three types of coumarin derivatives(compounds 1,2,3) against three high resistance $V$. choleraee $(3,5,6)$ were studied and results shown in the table(2) at which the compound 3 show the highest effect at which the diameter of inhibition zone was $(12,15$ and $14 \mathrm{~mm})$ against $V$. choleraee isolates, 3,5,6 respectively ,While the compound 1 was have a moderately effect at which the diameter of inhibition zone was $(10,12$ and $12 \mathrm{~mm})$. While the compound 2 was lowest effective by producing the inhibition zone of $(0,11$ and $10 \mathrm{~mm})$ against the above isolates respectively.

Our results was in agreement with Coixia etal, 2014 who found that many compounds containing chromene ring moiety display broad spectrum of biological activity. $2 \mathrm{H}$-Chromenes have gained much attention 
because of various biological activities such as antiviral, anti-tumor, anti-bacterial, fungicidal, antiflamatory, antioxidative and activator of potassium channels effects ${ }^{(22)}$.Coumarin $(2 \mathrm{H}-$ 1-benzopyran-2-one), a naturally occurring plant constituent, has been used in the treatment of cancer and edema, and many of its derivatives have also shown biological activity. include antibacterial ${ }^{(23)}$.

Table (2): Antimicrobial activity of the coumarim compounds against Vibrio cholera isolates.

\begin{tabular}{|c|c|c|c|}
\hline $\begin{array}{l}\text { compounds } \\
\text { Bacteria } \\
\text { isolation }\end{array}$ & $\begin{array}{c}(\mathrm{Co}(\mathrm{C10H5} \mathrm{ClO4}) 2 \mathrm{Cl2}) \\
\text { Compound (1) }\end{array}$ & $\begin{array}{c}(\mathrm{Mn}(\mathrm{C} 10 \mathrm{H} 5 \mathrm{ClO} 4) 2 \mathrm{Cl} 2) \\
\text { Compound (2) }\end{array}$ & $\begin{array}{c}\text { (Co(C10H5 ClO4)2 } \\
\text { Cl2 }) \\
\text { And } \\
(\mathrm{Mn}(\mathrm{C10H5} \\
\text { ClO4)2Cl2) } \\
\text { Compound }(3)\end{array}$ \\
\hline \multicolumn{4}{|c|}{ Inhibition zone in $\mathbf{m m}$} \\
\hline Isolation no 3 & 10 & $\begin{array}{l}\mathbf{0} \\
\end{array}$ & 12 \\
\hline Isolation no 5 & 12 & 11 & 15 \\
\hline Isolation no 6 & 12 & 10 & 14 \\
\hline
\end{tabular}

The effect of acridine orange concentrations on Antibiotic sensitivity of three highly resistance $V$. cholerae isolates.

The results of the effect of acridine orange on athree higher resistance $V$. cholerae $(3,5,6)$ were studied and shown as in table $(3)$. These results showed that three $V$. choleraee isolates became sensitive to Ciprofloxacin, Norfloxacin and ceftrixone till $10^{-6}$ concentration of acridine orange While still resistance to the remained five antibiotics under this study.
Also, the results of agarose electrophoresis were shown in figure 3 revealed the presence of plasmid DNA bands of $(472,670,520$ \& 950)bp in $(3,5,6,7)$ isolates respectively and chromosomal band in normal cases, while the presence of one chromosomal band isolate 8 which treated with acridine orange at concentration of $\left(10^{-2}\right.$ to $\left.10^{-4}\right)$. The effect of keylating agent (acridine orange) may cause a genetic mutations due to the changes in antibiotics resistance types of curing isolates after one hour of electrophoresis

Table (3): The effect of acridine orange concentrations on Antibiotic sensitivity of three highly resistance $V$. choleraee isolates $(3,5,6)$.

\begin{tabular}{||c|c|c|c|c|c|c|c|c||}
\hline $\begin{array}{l}\text { Acridine } \\
\text { orange } \\
\text { con. }\end{array}$ & Cip. & Nor. & Ery. & Amp. & Ceft. & Amk. & Chlora. & Co-tri. \\
\hline 0 & RRR & RRR & RRR & RRR & RRR & RRR & RRR & RRR \\
\hline $10^{-1}$ & SSS & SSS & RRR & RRR & SSS & RRR & RRR & RRR \\
\hline $10^{-2}$ & SSS & SSS & RRR & RRR & SSS & RRR & RRR & RRR \\
\hline $10^{-3}$ & SSS & SSS & RRR & RRR & SSS & RRR & RRR & RRR \\
\hline $10^{-4}$ & SSS & SSS & RRR & RRR & SSS & RRR & RRR & RRR \\
\hline $10^{-5}$ & SSS & SSS & RRR & RRR & SSS & RRR & RRR & RRR \\
\hline $10^{-6}$ & SSS & SSS & RRR & RRR & SSS & RRR & RRR & RRR \\
\hline $10^{-7}$ & RRR & RRR & RRR & RRR & RRR & RRR & RRR & RRR \\
\hline $10^{-8}$ & RRR & RRR & RRR & RRR & RRR & RRR & RRR & RRR \\
\hline $10^{-9}$ & RRR & RRR & RRR & RRR & RRR & RRR & RRR & RRR \\
\hline $10^{-10}$ & RRR & RRR & RRR & RRR & RRR & RRR & RRR & RRR \\
\hline \hline
\end{tabular}

These results were in agreement with Hopwood etal, 1995 and pang etal 2007 who study the role of many antibiotic resistance properties of different serotypes of V.cholera which were plasmid determined and affected by many mutagenic agents ${ }^{(24,25)}$.

Our results were in contrast with Pavlov etal 2006 who found that genetics of actinorhodine -production by Streptomyces 
coelicolor was chromosomally determined and curing isolates treated with EthidiumBromide still actinorhodine producers. ${ }^{(26)}$.Another study showed the presence of only one mega plasmid band of Bacillus thuringensis after 1:30h of electrophoresis while, there is a complex plasmid profile with different molecular weights occur within the same species. This reason may related to the differences of plasmid properties between strains related to the same species or even sub species level ${ }^{(27)}$.
Bora etal 1994 found that these differences in plasmid profile may caused by the differences in the method of DNA separation, the molecular weights of plasmid and its copy number found in bacterial cells ${ }^{(28)}$.Our results may help to investigate the effect of coumarin derivative on another pathogenic bacteria even anti-tumor activity, also it was important to determined the specific gene sequence of cured isolate and the effect of acridine orange on other virulence factors of more epidemiological agents in Iraq.

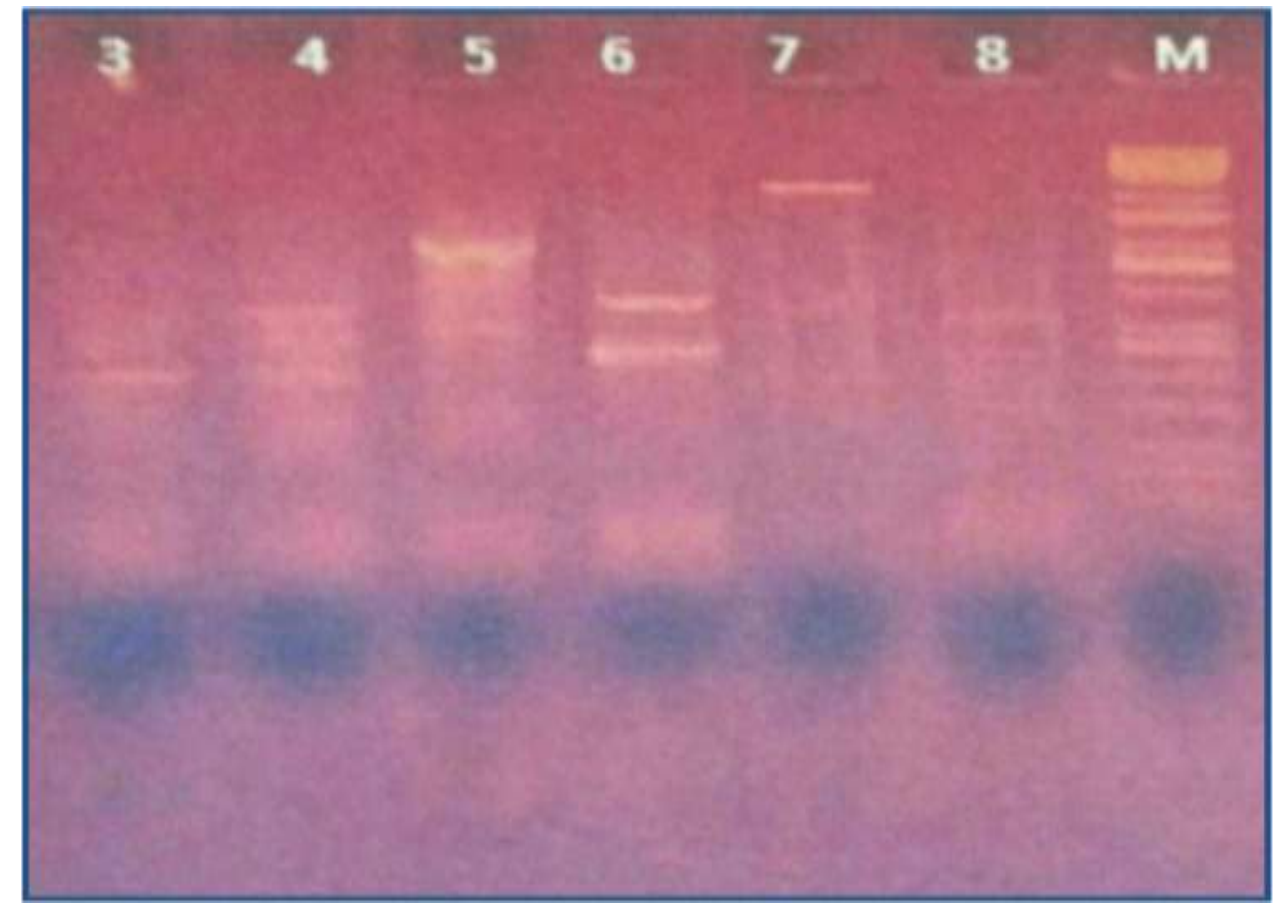

Figure (3): Agarose gel electrophoresis of both chromosomal and plasmid DNA isolated from $V$. choleraee Iraqi isolates. Lane 3,5,6,7 represent the normal isolates; lane 4 represents repeated normal isolate (3). Lane 8 represents treated isolate with Acridine orange at concentration $\left(10^{-2}\right)$; lane $M$ represents a marker.

\section{References}

1. Forbes, B. A; Sahm; D. F. and Weissfeld, A. S. Baily and Scott's.Diagnostic Microbiology. 12th ed. Mosby Elsevire. 2007; P: 371-8.

2. Faraque, S. M., Tam, V. C.; Chowdhury, N., Diraphat, P.; Dziejman, M; Heidelberg, J. F. Genomic analysis of the Mozambique strainsof Vibrio choleraee $\mathrm{O} 1$ reveals the origin of ELTOR strains carrying classical CTX prophage. Proc. Nath. Acad Sci. 2007; 104: 5151-6.

3. Farugue, S. M. ; Al bert, M.J. and Mekalanos, J. J. Epidemiology ,genetics, and ecology of toxigenic Vibrio choleraee. Microbiology and molecular Biology Review1998; 62 (4): 13014.
4. Faruqu, S. M.; Chowdhury, N.; Kamruzzaman , N.; Dziejman, M.; Rahman , M.H.; Sack, D.A.; Nair, G.B.; and Mekalanos, J.J. Genetic diversity and virulence potential of environmental Vibrio choleraee population in a cholerae-endemic area. PNAS. 2004; 101(7):2123-8.

5. Joshi, R.M. and Albert, M.J.. Hybrid ELtor Vibrio choleraee O1Emerg. Infect. Dis. 2009;15 (11): 1879-80.

6. Tagomori, k.; Iida, T. and Honda, T. Comparision of genome structures of Vibrios, bacteria possessing two chromosomes. J. Bacteriol. 2002; 184(16):4351-58.

7. $\mathrm{Xu}, \mathrm{Q}$.; Dziejman, M. and Mekalanos, J. J. Determination of the transcriptome of Vibrio choleraee 
during international growth and midexponenttial phase in vitro. Proc. Natl. Acad. Sci. USA. 2003; 10 (13):1286- 91.

8. Heinemann, S. A. ; Thomson, F. K. and Hynes, W. L.. Plasmid-Borne antibiotic Resistance in Vibrio choleraee isolated From Shop'sBallast water. J. Microbiol. 2003;(2): 223138.

9. Coppo, A.; Colombo,M.; Pazzani, C.; Bruni, R.; Savia, A. and Miamone,F. $V$. choleraee in the Horn of Africa: epidemiology, plasmid,Tetracyclinie, resistance gene implication and comparison between O1and non-O1. Am. J. Trop. Med. Hyg.1995; 53 (4):351-59.

10. Basu, A.; Garg, P. ; Datta, S.; Ghakraborty, S. ; Bhatt acharya, T.; Khan,A.; Rammurthy. T.; Bhattacharya, S. K.; Yamasaki, S. ; Taked, Y. and ,G. B.. Vibrio choleraee 0139 in Calcutta, 19921998. Incidence,Antibiogram and genotypes. Emerg. Infect. Dis.2000; 6 (2): 139- 47.

11. Wilson, G.; Miles, A. and Parker, M. T. Topley. And Wilson's principles of Bacteriology, Virology and Immunity. $\left(7^{\text {th.ed }}\right) . \quad(1983) ;$ 2.Edward Arnold. London.

12. Sousa, L.R. and .Larson ,M; J.Am.Chem.Soc. 1983;100,P:477.

13. Jschneider ,H. and .Dürl ,H; ,(1991).Frontiers in Supramolecular Chemistry and Photochemistry, $v$ $\mathrm{CH}$, Weinheim.

14. Leal, L.K.A.M.; Ferria, A.A.G.; Benzeera, G.A and Viana, G.S.B. Anticonceptive, anti-inflommatory and Branchiodilator activities of Brazilian Medical plants containing coumarin J. of Ethnopharmacology 2006;70(2): 151-59.

15. Baron, E. J. ; Petersond, L. R. and Finegold, S. M.. In Baily \&

Scott's. Diagnostic microbiology (9 thed) (Mosby. St. Louis, Baltimore. 1994:Pp 429- 30.

16. Stavric, S. and Bachanan, B. (1995). The Isolation and Identificationof $V$. choleraee $\mathrm{O} 1$ and non $\mathrm{O} 1$ From Foods. Research Division, Bureau of Microbial Hazard, Food Directorate Health, Canada. Ottawa.

17. Bauer, A. W.; Kirby, W. M.; Herris, J. C. and Turtch, M.Antibiotic susceptibility testing by standardized single disk methedA. J.Clin. Path., . 1966;43: 493- 96.

18. Jurd King, L and . Mihara K, Experientia, 1970;26:1281

19. Lino, C.S.; Taveiva, M.L.\&Matos, F.J.A. Analgesic \& anti-inflammatory of Jesticia pectoralis and it's main constitute comarine and umbileferine. Phgtotherapg Research. 1997; 11 (3): 211-15.

20. AL- Obidi, I. M.. Determination of some epidemiological markers in locally isolated Vibrio choleraee. M. Sc. Thesis, College of Science, University of AL- Mustansiriah.2005.

21. Kirby, A.S.; Posplech ,A.K.and Neuman,E.D Laboratory Manual of Experimental Microbiology.( $2^{\text {nd }}$ ed.). John Innes Center, Norwich, NR4, $7 \mathrm{UH}, \mathrm{UK}$

22. Caixia Wang, Cuilian $\mathrm{Xu}$, Guoyu Yang, Sufang Fan, Li Xin and Tingting Guo . 6-Chloro-2-hydroxy2-trifluoromethyl-2H-chromene-3carboxylic acid (5-allylsulfanyl $(1,3,4)$ thiadiazol-2-yl)- amide Molbank 2014; M830; doi :10.3390 / M830 .

23. Bernadette, S. Creaven, Denise A. Egan a, Kevin Kavanagh, Malachy McCann, Andy Noble, Bhumika Thati and Maureen Walsh. Synthesis, characterization and antimicrobial activity of a series of substituted coumarin-3-carboxylatosilver(I) complexes, Inorganica Chimica Acta 2006; 359 :3976-84.

24. Hopwood,D.A.;Chater,K.F.and Bibb,M.J. Genetic regulation of Antibiotic production. Ciba.found. Symp. 1995;118:64-74.

25. Pang , B; Yan , M.; Cui,Z.;Zhang ,L.and Kan ,B.Genetic diversity of toxigenic and not toxigenic $V$. cholera serogroups $\mathrm{O} 1$ and $\mathrm{O} 139$ revealed by array-based comparative genomic hybridization.J. Bacteriol . $2007 ; 189$ :4837 - 49.

26. Pavlov ,A.R.,Pava, N.V. ; Kozyavkin , S.A. and Slesarev, A.I. Thermostable DNA polymerase for a wide spectrum of applications : comparison of aRobust hybrid Topotaq to other enzymes .In Kieleczawa . J.DNA Sequencing II : optimizing prepration and cleanup.2006: pp. 241-57.ISBN.

27. Mohammed, A.J.; Abdul Kareem AlKazaz and Ali, S.M. plasmid Role in crystal protein production in Locally 
isolated Bacillus thuringesis Iraqi J. of science. 2013: P301-6.

28. Bora, R.S.; Mutry M.G. and sekar, V. Introduction to lepidopteran- specific insecticidal crystal protein gene of
Bacillus thuringesis subspecies

Kurstaki by conjugal transfer in cotton phyllo sphere. Appl. Environ .Microbiol. 1994; 60: 214-22. 